\title{
Høreapparat til besvær
}

«Piper jeg?,» spurte jeg min sidemann på trikken. Han så forundret på meg. «Piper jeg?,» gjentok jeg. Han prøvde å avlede meg ved å spørre om jeg skulle langt med trikken. Jeg svarte at jeg skulle nedi sentrum, men at det jeg spurte om var om jeg pep. Det ble stille. Irriterende saker! «Kan du være så snill å svare på om jeg piper?»

Mannen henvendte seg til damen bak. «Kan du forstå hva i all verden den mannen her snakker om? Jeg forstår ikke hva han mener med om han piper.» Jeg har forstått etterpå at damen sannsynligvis har svart noe om at det kanskje er om det piper $\mathrm{i}$ brystet. I alle fall hadde det seg slik at min sidemann segnet om med hodet på min brystkasse. Som gammel lege tok jeg straks signalet om et illebefinnende, så jeg ropte ut $i$ trikken at jeg var doktor Engeset og at noen måtte ringe sykebilen øyeblikkelig.

Det ble stor oppstandelse og trikken hadde stanset opp. Jeg ønsket å få mannen ned på gulvet og famlet etter armen hans for å føle pulsen. Han hadde imidlertid kommet seg betraktelig og grep tak i jakkekragen min og sa at det måtte ha rablet for meg. Ambulansepersonalet kom raskt til stedet. Før jeg visste ordet av det ble jeg båret ut av trikken.

Da jeg ble trillet inn i mottakelsen, ble jeg møtt av en vennlig sykepleier som sa: «Høreapparatet ditt piper, dr. Engeset.»

\section{Arnfinn Engeset}

Oslo

Mottatt 18.11. 2010 og godkjent 2.12. 2010. Medisinsk redaktør Erlend Hem.

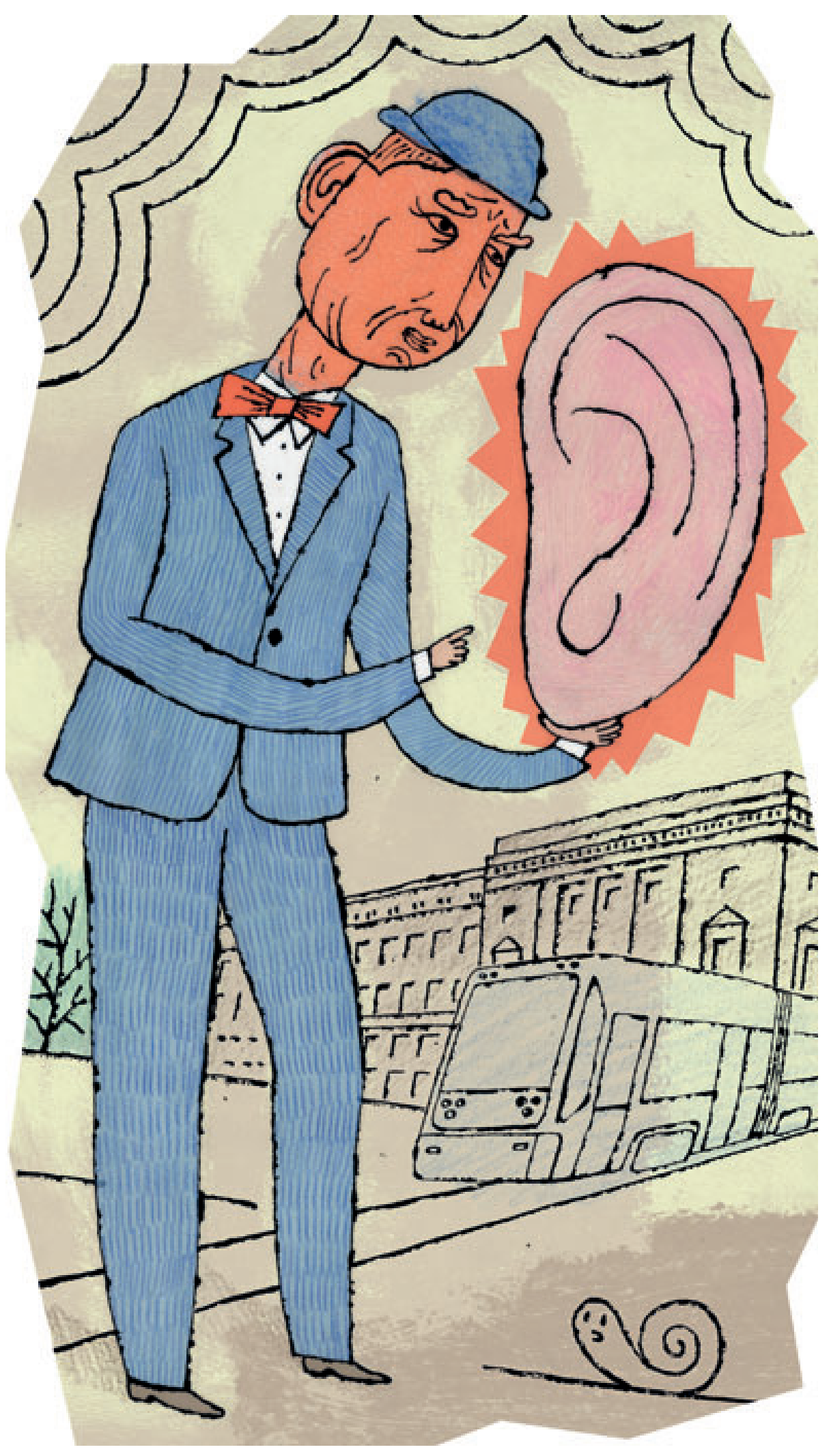

Illustrasjon Svein Størksen 